\title{
O ENSINO RELIGIOSO NAS ESCOLAS PÚBLICAS BRASILEIRAS E O PRINCÍPIO DA LAICIDADE A PARTIR DA ÉTICA DA HOSPITALIDADE
}

\author{
RELIGIOUS EDUCATION IN BRAZILIAN PUBLIC SCHOOLS AND THE \\ PRINCIPLE OF SECULARITY FROM THE ETHICS OF HOSPITALITY
}

\section{Eder Bomfim Rodrigues ${ }^{1}$}

Resumo: Os debates que envolvem o ensino religioso nas escolas públicas e o princípio da laicidade têm sido uma realidade no Brasil, principalmente a partir das mudanças na Lei de Diretrizes e Bases da Educação Nacional em 1997 e da assinatura do Acordo entre o Governo da República Federativa do Brasil e a Santa Sé relativo ao Estatuto Jurídico da Igreja Católica no Brasil em 2008. Tudo isso num país marcado por uma forte presença do cristianismo católico na vida das pessoas e na esfera estatal. Assim, este trabalho busca analisar o princípio da laicidade e o ensino religioso nas escolas públicas a partir do reconhecimento da ética da hospitalidade, num processo mais democrático e aberto de inclusão do outro e de um pluralismo religioso.

\section{Palavras-chave: ENSINO RELIGIOSO. LAICIDADE. HOSPITALIDADE.}

\begin{abstract}
Discussions involving religious education in public schools and the principle of secularity have been a reality in Brazil, mainly after changes in the Law of Guidelines and Fundaments of National Education in 1997 and the signing of the Agreement between the Government of the Federative Republic of Brazil and the Holy See concerning the legal status of the Catholic Church in Brazil in 2008. All of this in a country marked by a strong presence of the Catholic Christianity in people's daily life and at the state level. This work seeks to analyze the principle of secularity and religious education in public schools from the perspective of the ethics of hospitality, which proposes a more democratic process, open to the inclusion of the other and to religious pluralism.
\end{abstract}

Key words: RELIGIOUS EDUCATION. LAITY. HOSPITALITY.

1 Doutor pela Pontifícia Universidade Católica de Minas Gerais, Belo Horizonte, Minas Gerais, Brasil. 
Keywords: RELIGOUS EDUCATION. SECULARITY. HOSPITALITY.

\section{INTRODUÇÃO}

As discussões em torno do ensino religioso nas escolas públicas e do princípio da laicidade têm sido um realidade no Brasil, principalmente a partir das mudanças que ocorreram na Lei de Diretrizes e Bases da Educação Nacional, em 1997, e com a assinatura do Acordo entre o Governo da República Federativa do Brasil e a Santa Sé relativo ao Estatuto Jurídico da Igreja Católica no Brasil em 2008.

É fato que a história brasileira é marcada pela presença do cristianismo católico na vida das pessoas e na esfera estatal. Desde 22 de abril de 1500, essa tradição religiosa tem deixado as suas marcas, compondo a identidade nacional e as relações políticas e sociais. Tudo isso fruto de um incansável trabalho da Igreja Católica e da Companhia de Jesus.

Os jesuítas contribuíram enormemente para a formação do Brasil, pois, além de missionários da Igreja, foram responsáveis pela educação e pela difusão do conhecimento. Assim, todo o ensino permaneceu, durantes séculos, sob os cuidados da Igreja Católica, o que acarretou consequências na educação e na legislação nacional. Dentre elas, pode-se citar, hoje, a existência do ensino religioso nas escolas públicas, com previsão não só na legislação infraconstitucional, mas também na própria Constituição da República.

No entanto, a discussão existente no Brasil não diz respeito apenas ao ensino religioso, mas também ao princípio da laicidade, que tem sido compreendido como sinônimo de uma separação entre Estado e religião e de neutralidade estatal. Tais argumentos, inclusive, estão presentes na Ação Direta de Inconstitucionalidade 4439, no Supremo Tribunal Federal, (STF) e levam toda essa questão do ensino religioso para análise pelo Judiciário. Por outro lado, a laicidade vem sendo identificada como se fosse laicismo, o que causa sérias consequências à liberdade religiosa e às relações entre Estado e religião.

Diante disso, é possível afirmar que o princípio da laicidade significa apenas separação e neutralidade estatal? Há realmente um distanciamento total entre Estado e religião? Como compreender e como compatibilizar o ensino religioso nas escolas públicas com a laicidade? Este trabalho busca responder as questões propostas a partir do reconhecimento da ética da hospitalidade de Derrida (2003), de forma que a laicidade seja fundamentada nas bases de uma responsabilidade incondicional ao outro, de modo a promover também uma nova compreensão para o ensino religioso. 


\section{AS ORIGENS DA RELIGIOSIDADE NA FORMAÇÃO DO BRASIL}

A chegada dos portugueses ao Brasil em 22 de abril de 1500 foi um momento de grande importância na história de Portugal e das Américas, pois demonstrou a força do poderio português em seu processo de expansão colonial pelo mundo e possibilitou uma nova história para o continente americano. No entanto, o colonialismo português não se resumiu apenas a um projeto de ordem econômica, visto que a difusão da fé católica em terras longínquas foi também um objetivo que impulsionou aquele país a se lançar ao mar.

Os colonizadores portugueses consideravam-se missionários da Igreja Católica para a salvação de almas que desconheciam a mensagem da Bíblia. E Portugal agiu para facilitar esse processo de propagação da fé ao possibilitar que os padres estivessem presentes em todas as grandes viagens realizadas. Assim, era muito comum ter um religioso nas embarcações, tal como aconteceu na viagem liderada por Pedro Álvares Cabral, que chegou ao território que hoje é o Brasil.

\footnotetext{
Também alojados sob as cobertas do navio iam os religiosos - com exceção do frei D. Henrique Soares de Coimbra, ao qual fora reservado um camarote ao lado do de Cabral. Homem de vasto saber teológico e político, D. Henrique largara a toga de desembargador da Casa de Suplicação de Lisboa para entrar como noviço no convento de Alenquer. Após a viagem ao Brasil, ele se tornaria bispo de Ceuta, confessor do rei D. Manoel e embaixador em missões junto aos papas Júlio II e Leão $\mathrm{X}$. Mais tarde, teria sido inquisidor - e presidido a primeira queima de um judeu em Portugal na praça de Olivença. (BUENO, 1998, p. 39).
}

As marcas da religiosidade católica se fizeram presentes no Brasil desde o início de sua formação, inclusive com a primeira missa realizada no dia 26 de abril de 1500, na praia de Coroa Vermelha, hoje cidade de Porto Seguro, Bahia. Um exemplo direto que demonstrava as intensas relações entre Portugal e a Igreja Católica, as quais tiveram origem na época do seu primeiro rei, Dom Afonso Henriques (1143-1185).

Analisar a proximidade das relações entre o Estado português e a Igreja Católica é fundamental para se compreender as primeiras práticas sociais estabelecidas no território brasileiro, ainda mais diante de uma formação que ocorreu dentro de forte perspectiva religiosa, cujas marcas estão presentes até os dias atuais. Assim, não se pode pensar no processo de colonização do Brasil sem a efetiva participação da Igreja Católica que, desde o 
início dos anos de 1500, demonstrou um grande interesse na expansão da fé no Novo Mundo e na conversão dos indígenas, contando inclusive com a contribuição dos jesuítas.

\begin{abstract}
Nascido à sombra da Cruz, o Brasil recebeu os jesuítas apenas nove anos depois da criação da Companhia de Jesus. Em 1549, com o Governador Tomé de Sousa, chegou à Bahia a primeira leva de inacianos. Chefiava-a quem tinha qualidades de organizador, político e missionário: Manuel da Nóbrega. Por vinte e um anos seria êle o Superior, o Provincial, o Reitor, a quem tudo se ficou devendo; o trabalhador incansável das viagens pelo litoral, o arguto conselheiro da fundação do Rio de Janeiro, o fundador dos três Colégios que são as mais ricas jóias do verdadeiro tesouro que nos legaram os jesuítas. (VIANNA, 1970, p. 99-100).
\end{abstract}

O trabalho de evangelização dos jesuítas marcou a formação do Brasil, pois possibilitou uma maior e mais eficiente expansão do catolicismo no território colonial, bem como funcionou como um importante instrumento de controle social para o estabelecimento das bases morais da sociedade colonial, com seus costumes e práticas.

Os padres da Companhia de Jesus serviram ainda como agentes de formação do saber em diversas áreas, tendo também fundado várias escolas em muitas regiões do Brasil. “Os colégios dos jesuítas nos primeiros dois séculos, depois os seminários e colégios de padre, foram os grandes focos de irradiação da cultura no Brasil colonial.” (FREYRE, 2002, p. 504). Na verdade, os jesuítas exerceram, com o apoio da Coroa portuguesa, o monopólio absoluto do ensino na colônia, tendo tal situação perdurado até o século XVIII, quando eles foram expulsos do Brasil pelo Marquês de Pombal. Os jesuítas foram

\footnotetext{
criadores de nosso ensino, de nosso teatro e, de certo modo, de nossa medicina e de nossa arquitetura; preservadores das línguas indígenas; cronistas de todos os acontecimentos aqui registrados; primeiros intelectuais que exerceram atividades literárias na colônia - desempenharam uma incumbência para a qual não faltavam qualificativos, tão grande e tão excepcional foi ela, entre tôdas que contribuíram para a formação do Brasil. (VIANNA, 1970, p. 103).
}

Pode-se dizer que o jesuíta "foi primeiramente Educador, isto é, Mestre da intelligencia e formador do carácter." (CABRAL, 1925, p. 148). Por meio da educação, eles influenciaram a forma cotidiana de pensar nos tempos da colonização. Dessa forma, a chegada dos jesuítas foi marcada pela tradicional catequese e, também, por um trabalho formidável em favor da educação em terras brasileiras. No entanto,

como responsável pelo ensino, a Igreja manteve o povo analfabeto. O aprendizado do catecismo fazia-se oralmente. Só a aristocracia e os brancos mais ricos eram alfabetizados, em casa ou nos conventos dos jesuítas. Não se fundou sequer uma escola superior na colônia. Surgiu uma elite "intelectual" caricata, condicionada pelos preconceitos do escravismo. Os padres ensinavam que os senhores deviam ser 
bons e os negros obedientes. A contribuição da Igreja à deformação ideológica representou um auxílio significativo ao não-questionamento intelectual do escravismo. (CHIAVENATO, 2002, p. 37).

Assim, a influência dos padres na educação dos filhos do senhor de engenho foi uma constante em todo o período colonial. O ensino ficou a cargo dos clérigos e acontecia sob a supervisão e o cuidado da Igreja. Segundo relata Freyre (2002, p. 504),

até meados do século XIX, quando vieram as primeiras estradas de ferro, o costume nos engenhos foi fazerem os meninos os estudos em casa, com o capelão ou com mestre particular. As casas-grandes tiveram quase-sempre sala de aula, e muitas até cafua para o menino vadio que não soubesse lição. Muitas vezes aos meninos se reuniam crias e moleques, todos aprendendo juntos a ler e a escrever; a contar e a rezar. Noutros engenhos cresceram em igual ignorância meninos e moleques.

O catolicismo esteve presente na base de formação do Brasil, sendo uma consequência direta da influência portuguesa na estruturação da colônia e um elemento constitutivo da identidade e da unidade nacional, que foi "assegurada pelo catecismo e pelas Ordenações, pela liturgia Católica e pela língua portuguesa auxiliada pela 'geral' de criação jesuítica." (FREYRE, 2002, p. 176).

Contudo, por mais que o trabalho dos jesuítas no Brasil tenha tido a sua importância e tenha deixado as suas marcas, não se pode negar que a Igreja cometeu inúmeros equívocos e falhou na valorização da vida e da dignidade humana. O catolicismo foi responsável direto pela morte de milhares de indígenas e de escravos de origem africana no período colonial, bem como pela destruição da cultura desses povos. Uma violência nunca antes vista na história das Américas e que marcou não só a colonização portuguesa, mas também a de outros povos europeus que chegaram ao continente nos séculos XVI e XVII. De todo modo, não se pode pensar na história do Brasil sem a presença marcante da Igreja Católica e dos jesuítas e sem os diversos serviços prestados pelos inúmeros padres na colonização.

Portanto, o cristianismo de tradição católica tornou-se um elemento formador e constitutivo da identidade brasileira, ganhando uma posição de destaque que foi fundamental para a organização do Brasil após o processo de independência em 1822 e na Constituição do Império de 1824. Uma marca que, mesmo com a Constituição da República de 1988 e o Estado Democrático de Direito, tem gerado consequências nos debates que envolvem o princípio da laicidade, a liberdade religiosa e o ensino religioso nas escolas públicas do país. 


\section{O ENSINO RELIGIOSO NA CONSTITUIÇÃO, O ACORDO ENTRE O BRASIL E A SANTA SÉ E A ADI 4439}

A Constituição Política do Império do Brasil de 25 de março de 1824, texto outorgado pelo Imperador Dom Pedro I (1822-1831), foi o primeiro texto constitucional brasileiro. A Constituição foi responsável por afirmar vários direitos fundamentais e por manter em sua estrutura laços de proximidade do Estado com a Igreja Católica, ao estabelecer, por exemplo, o catolicismo como religião oficial do Império e adotar o regime do padroado no Brasil, regime este em que o monarca assumia uma função primordial na administração da Igreja.

A Constituição de 1824 legitimou a presença da religião católica no Estado e na vida brasileira. Com isso, abriu a possibilidade para a existência do ensino do catolicismo nas escolas públicas. Assim, a Lei de 15 de outubro de 1827, que dispôs sobre a criação de escolas em todas as cidades, vilas e lugares mais populosos do Império estabeleceu o seguinte:

\footnotetext{
Art. $6^{\circ}$ Os professores ensinarão a ler, escrever, as quatro operações de aritmética, prática de quebrados, decimais e proporções, as noções mais gerais de geometria prática, a gramática de língua nacional, e os princípios de moral cristã e da doutrina da religião católica e apostólica romana, proporcionados à compreensão dos meninos; preferindo para as leituras a Constituição do Império e a História do Brasil. (BRASIL, 1827).
}

A Lei de 15 de outubro de 1827 foi a primeira a regulamentar o ensino religioso no Brasil e funcionou como um instrumento de difusão do catolicismo nas escolas públicas, situação essa que se alterou profundamente com a Proclamação da República em 15 de novembro de 1889.

A instituição da forma republicana no Brasil provocou muitas mudanças, dentre elas a que envolveu o modelo de relações existentes entre Estado e Igreja. O Decreto 119-A, de 07 de janeiro de 1890, proibiu a intervenção da autoridade federal e dos Estados federados em matéria religiosa, consagrou a plena liberdade de cultos e extinguiu o padroado. O Decreto 119-A/1890 instituiu o Estado laico e separou o Estado da Igreja.

O modelo de laicidade estabelecido no Decreto 119-A/1890 se repetiu na Constituição da República dos Estados Unidos do Brasil de 24 de fevereiro de 1891. Essa Constituição, influenciada pelo positivismo francês e pela doutrina liberal, promoveu uma 
radical separação entre Estado e Igreja e secularizou várias áreas da vida e das relações sociais que antes estavam sob o cuidado da Igreja Católica. Dentre elas, pode-se citar o fim do ensino religioso nas escolas públicas, conforme previsto no art. $72, \S 6^{\circ}$, da Constituição de 1891.

No entanto, a laicidade proclamada pela Constituição de 1891 não conseguiu se impor de forma absoluta em toda a República Velha (1889-1930). A força do catolicismo e dos seus preceitos na sociedade brasileira fez com que o ensino religioso retornasse para as escolas públicas como forma de se combater o processo de retirada da religião do espaço público. Tal situação aconteceu, por exemplo, em Minas Gerais, por meio da Lei 1.092 de 12 de outubro de 1929, que permitiu a instrução religiosa nas escolas públicas mineiras no horário das aulas.

Ora, por mais que a separação entre Estado e Igreja tenha sido muito criticada pelos clérigos católicos, tal fato foi importante para a autonomia e a liberdade de ação da Igreja, pois ela "libertou-se da tutela estatal, uniu-se ao Vaticano, organizou-se, romanizou-se, disciplinou e moralizou seus quadros.” (MARIANO, 2001, p. 145-146). A Igreja passou por um novo momento em sua história no Brasil, uma fase de expansão de suas atividades, seja no âmbito eclesiástico, seja em seu trabalho em áreas como a educação. Essa situação implicou o crescimento das escolas católicas em todo o país, as quais funcionavam como um meio de difusão da fé cristã.

O período da República Velha foi importante na história da Igreja Católica, pois ela agiu para não perder o espaço conquistado na colonização e no Império. Com isso, ela buscou combater a separação do Estado instituída pelo regime republicano e investiu em suas relações com as elites dos diferentes Estados-membros, seja no âmbito do ensino, seja fazendo-se presente nos mais diversos acontecimentos da vida pública e privada.

\footnotetext{
Nas condições da época, a Igreja ainda ocupava espaços consideráveis nas áreas de saúde, educação, lazer e cultura. Presidia à organização das festas e comemorações coletivas (procissões, quermesses etc.), fazendo coincidir o calendário de festas e eventos religiosos com os momentos fortes de efusão coletiva e doméstica. [...] Ungia os dirigentes das irmandades, os detentores de mandatos parlamentares e executivos, dispensava diplomas e certificados escolares, sacramentava formaturas, inaugurações, posses e acordos políticos, benzia prédios públicos, residências, fazendas, fábricas, geria hospitais, dispensários, asilos, escolas, marcando presença em quaisquer dimensões da vida social. (MICELI, 2009, p. 34).
}

Com a Revolução de 1930, uma grande mudança aconteceu nas relações entre Estado e Igreja e na questão que envolvia o ensino religioso nas escolas públicas. A Igreja exerceu uma forte pressão no novo governo para que a sua luta, que vinha desde os tempos da 
República Velha, se tornasse uma realidade e ela pudesse ocupar mais espaço na sociedade, de modo a influenciar as ações estatais, ter mais privilégios e exercer mais poder.

A Igreja Católica se aproximou do Governo de Getúlio Vargas e buscou junto aos novos governantes a satisfação de seus interesses. Para isso a Igreja apoiou o Governo que ora se iniciava e, em troca, foi-lhe garantida ocupar parte do espaço perdido com o Decreto 119A/1890 e depois com a Constituição de 1891. Assim, em 30 de Abril de 1931, por meio do Decreto 19.941, Getúlio Vargas atendeu aos vários pedidos da Igreja e fez com que a instrução religiosa voltasse às escolas públicas. $O$ ensino seria facultativo nos estabelecimentos educacionais de nível primário, secundário e normal, os quais garantiam aos alunos a possibilidade de dispensa no ato de matrícula.

A situação política favorável à Igreja Católica gerou frutos na nova Constituição da República dos Estados Unidos do Brasil promulgada em 16 de julho de 1934. A nova ordem constitucional buscou superar um sistema de hostilidade à religião e inaugurou um modelo de cooperação recíproca em prol dos interesses coletivos, tal como previsto no art. 17, III da Constituição. Quanto ao ensino religioso, o art. 153 trouxe a previsão de que seria uma matéria dos horários nas escolas públicas primárias, secundárias, profissionais e normais, mas de frequência facultativa e ministrado de acordo com a confissão religiosa dos alunos, que, por sua vez, deveria ser manifestada pelos pais ou responsáveis.

Todavia, a Constituição de 1934 não resistiu muito tempo, pois conflitos políticos no país levaram Getúlio Vargas a dar um golpe de Estado, em 10 de novembro de 1937, e implantar o Estado Novo com a outorga de uma nova Constituição ao Brasil.

A Constituição de 1937 buscou promover uma separação radical entre Estado e religião no país, pois, ao contrário do texto constitucional anterior, não trouxe previsão de cooperação do Estado com as instituições religiosas. Para o ensino religioso, a Constituição estabeleceu que o mesmo seria contemplado como matéria do curso ordinário das escolas primárias, normais e secundárias e que não poderia, porém, constituir objeto de obrigação dos mestres ou professores, nem de frequência compulsória por parte dos alunos. Nesse sentido, o Decreto-Lei 4.244 de 9 de abril de 1942, que instituiu a lei orgânica do ensino secundário, dispôs em seu art. 21 que o ensino religioso constituía parte integrante da educação na adolescência, sendo lícito às escolas de ensino secundário incluir tal disciplina nos estudos do primeiro e do segundo ciclo e, ainda, que o conteúdo do ensino religioso, bem como de seu regime didático, seriam fixados pela autoridade eclesiástica.

Com o fim da Era Vargas, uma nova Constituição foi promulgada, a Constituição dos Estados Unidos do Brasil de 18 de setembro de 1946, a qual foi responsável por 
possibilitar, novamente, a colaboração recíproca em prol do interesse coletivo do Estado com alguma religião. Quanto aos aspectos que envolvem a educação religiosa, o art. 168, V, dispôs que "o ensino religioso constitui disciplina dos horários das escolas oficiais, é de matrícula facultativa e será ministrado de acordo com a confissão religiosa do aluno, manifestada por ele, se for capaz, ou pelo seu representante legal ou responsável.” (BRASIL, 1946).

A educação no Brasil passou por grandes mudanças na vigência da Constituição de 1946. Em 20 de dezembro de 1961 foi editada a Lei 4.024, que fixou as diretrizes e bases da educação nacional, a partir dos princípios da liberdade e dos ideais de solidariedade humana. Tal lei continuou a garantir a existência do ensino religioso no país, só que, naquele momento, sem ônus para o Estado.

\footnotetext{
Art. 97. O ensino religioso constitui disciplina dos horários das escolas oficiais, é de matrícula facultativa, e será ministrado sem ônus para os poderes públicos, de acordo com a confissão religiosa do aluno, manifestada por ele, se for capaz, ou pelo seu representante legal ou responsável.

$\S 1^{\circ}$ A formação de classe para o ensino religioso independe de número mínimo de alunos.

$\S 2^{\circ} \mathrm{O}$ registro dos professores de ensino religioso será realizado perante a autoridade religiosa respectiva. (BRASIL, 1961).
}

A Constituição de 1946 não teve uma longa vigência. O Golpe de 1964, orquestrado pelas Forças Armadas e por setores conservadores da sociedade civil brasileira, derrubou o governo do Presidente João Goulart e instalou a Ditadura Militar no país. Com isso uma nova Constituição foi aprovada em 1967, a qual também trouxe a previsão da colaboração de interesse público entre o Estado e as diferentes denominações religiosas.

A Emenda Constitucional $n^{\circ}$ 1/1969 manteve a colaboração entre Estado e religião, só que desta vez, de interesse público e nos limites de uma lei federal, especialmente nos âmbitos hospitalar, educacional e assistencial. Já o art. 176, § $3^{\circ}, \mathrm{V}$, da mesma Emenda, garantiu que o ensino religioso seria de matrícula facultativa, constituindo disciplina dos horários normais das escolas oficiais de primeiro e segundo graus. Nesse período ainda foi editada a Lei 5.692, de 11 de agosto de 1971, que fixou as diretrizes e bases do ensino de $1^{\circ} \mathrm{e}$ $2^{\circ}$ graus no país e estabeleceu para o ensino religioso a mesma diretriz constante na Emenda $n^{\circ} 1 / 1969$.

Com todo esse arcabouço legislativo, a Igreja Católica buscou estabelecer a sua hegemonia na condução do ensino religioso no país e isso fez com que essa disciplina tivesse as marcas fundamentais do catolicismo, a religião majoritária no país. Nem mesmo a promulgação da Constituição da República Federativa do Brasil, em 05 de outubro de 1988, 
conseguiu impedir que essa realidade fosse diferente, pois o ensino religioso continuou a ser uma disciplina com previsão constitucional.

Assim, o modelo de relações entre Estado e religião na Constituição da República de 1988 dá-se dentro de uma colaboração de interesse público, tal como previsto no art. 19, I do texto constitucional. Quanto ao ensino religioso, há previsão expressa para a sua existência. Segundo o art. 210, $\S 1^{\circ}$, da Constituição, "o ensino religioso, de matrícula facultativa, constituirá disciplina dos horários normais das escolas públicas de ensino fundamental." (BRASIL, 1988).

Com a nova ordem constitucional foi editada a Lei 9.394, de 20 de dezembro de 1996, que estabeleceu as diretrizes e bases da educação nacional, regulamentando o ensino religioso no ensino fundamental a partir de um modelo facultativo, sem ônus para o Estado e confessional ou interconfessional, tal como previsto no art. 33 da citada lei, in verbis:

\footnotetext{
Art. 33. O ensino religioso, de matrícula facultativa, constitui disciplina dos horários normais das escolas públicas de ensino fundamental, sendo oferecido, sem ônus para os cofres públicos, de acordo com as preferências manifestadas pelos alunos ou por seus responsáveis, em caráter:

I - confessional, de acordo com a opção religiosa do aluno ou do seu responsável, ministrado por professores ou orientadores religiosos preparados e credenciados pelas respectivas igrejas ou entidades religiosas; ou

II - interconfessional, resultante de acordo entre as diversas entidades religiosas, que se responsabilizarão pela elaboração do respectivo programa. (BRASIL, 1996).
}

O texto do art. 33 da Lei 9.394/1996 foi uma grande novidade para a época, pois admitiu a existência de um ensino religioso confessional e interconfessional nas escolas públicas. Todavia, tal dispositivo não agradou a Igreja Católica. Assim,

\footnotetext{
a hierarquia católica - oito meses depois de aprovada a Lei de Diretrizes e Bases da Educação (LDB) - conseguiu que o presidente da República, embora ateu de carteirinha, sancionasse emenda retirando do texto original da LDB a expressão "sem ônus para os cofres públicos". Com isso, o ônus financeiro do ensino religioso nas escolas públicas, em vez de pago pela Igreja e pelos católicos, passou a pesar no bolso dos contribuintes." (MARIANO, 2001, p. 159).
}

A Lei 9.475, de 22 de julho de 1997, alterou a redação originária do art. 33 da Lei 9.394/1996 para estabelecer um novo ensino religioso no Brasil, o qual deve ser visto numa perspectiva de formação do cidadão, constituindo uma disciplina dos horários normais das aulas e com ônus estatal. A mudança operada proporcionou ainda que o ensino religioso fosse realizado dentro de bases plurais e de diversidade cultural, não mais num caráter confessional 
ou interconfessional, e que a sociedade civil pudesse participar ativamente na construção do conteúdo da disciplina a ser ministrada em sala de aula.

\begin{abstract}
Art. 33. O ensino religioso, de matrícula facultativa, é parte integrante da formação básica do cidadão e constitui disciplina dos horários normais das escolas públicas de ensino fundamental, assegurado o respeito à diversidade cultural religiosa do Brasil, vedadas quaisquer formas de proselitismo.

$\S 1^{\circ}$ Os sistemas de ensino regulamentarão os procedimentos para a definição dos conteúdos do ensino religioso e estabelecerão as normas para a habilitação e admissão dos professores.

$\S 2^{\circ}$ Os sistemas de ensino ouvirão entidade civil, constituída pelas diferentes denominações religiosas, para a definição dos conteúdos do ensino religioso. (BRASIL, 1997).
\end{abstract}

A nova redação do art. 33 da Lei 9.394/1996 deixou o ensino religioso mais democrático, plural e aberto em respeito à diversidade religiosa existente no Brasil. Assim, a escola pública poderia tornar-se um ambiente de formação cidadã, de ensino da liberdade e da integração social. Com isso, rompe-se qualquer meio proselitista de ensino religioso e este torna-se um instrumento de análise crítica da religião e da realidade brasileira.

Entretanto, a discussão em torno do ensino religioso não terminou com o novo art. 33 da Lei 9.394/1996, pois em 13 de novembro de 2008 foi assinado o Acordo entre o Governo da República Federativa do Brasil e a Santa Sé relativo ao Estatuto Jurídico da Igreja Católica no Brasil. Tal tratado, firmado na Cidade do Vaticano quando da visita do Presidente Luiz Inácio Lula da Silva (2003-2010) ao Papa Bento XVI (2005-2013), representou um passo importante nas relações entre o Brasil e a Santa Sé e confirmou a proximidade histórica entre o país e a Igreja Católica.

Destaque-se que o Acordo de 2008 constitui um documento que busca consolidar normas jurídicas de aplicação às relações entre o Brasil e a Santa Sé, as quais estavam anteriormente contidas em textos esparsos, ora no direito interno, ora nos costumes ou no Direito Internacional. De acordo com Guimarães Neto (2009, p. 38),

o objetivo do presente Acordo é consolidar, em um único instrumento jurídico, diversos aspectos da relação do Brasil com a Santa Sé e da presença da Igreja Católica no Brasil, já contemplados na Convenção de Viena sobre Relações Diplomáticas, na Constituição Federal e em demais leis que configuram o ordenamento jurídico brasileiro. As diretrizes centrais seguidas pelas autoridades brasileiras na negociação do Acordo com a Santa Sé foram a preservação das disposições da Constituição e da legislação ordinária sobre o caráter laico do Estado brasileiro, a liberdade religiosa e o tratamento eqüitativo dos direitos e deveres das instituições religiosas legalmente estabelecidas no Brasil. 
O tratado em questão constitui um documento que é consequência direta da proximidade existente entre o Brasil e a Igreja Católica. Uma realidade que, segundo o próprio texto do Acordo, não viola o princípio da laicidade estabelecido no art. 19, I, da Constituição da República. Contudo, a despeito da afirmação acima, hoje há uma importante discussão no país relacionada ao art. 11 do Acordo de 2008, dispositivo este que diz respeito ao ensino religioso nas escolas públicas.

\begin{abstract}
Artigo 11. A República Federativa do Brasil, em observância ao direito de liberdade religiosa, da diversidade cultural e da pluralidade confessional do País, respeita a importância do ensino religioso em vista da formação integral da pessoa.

$\$ 1^{\circ}$. O ensino religioso, católico e de outras confissões religiosas, de matrícula facultativa, constitui disciplina dos horários normais das escolas públicas de ensino fundamental, assegurado o respeito à diversidade cultural religiosa do Brasil, em conformidade com a Constituição e as outras leis vigentes, sem qualquer forma de discriminação. (BRASIL, 2010a).
\end{abstract}

O texto consagrado no art. 11 não alterou substancialmente a realidade brasileira. Apenas apresentou uma situação já prevista, seja na Constituição ou na Lei de Diretrizes e Bases da Educação Nacional. Não há que se falar em violação ao princípio da laicidade ou até mesmo na realização de um tratamento especial, diferenciado e com privilégios para o catolicismo no ensino religioso. $\mathrm{O}$ art. 11 deve ser visto a partir da ética da hospitalidade, numa abertura de reconhecimento ao outro, de forma a serem acolhidas as mais distintas manifestações religiosas no processo de compreensão do fenômeno religioso como parte integrante da sociedade e que possibilita o respeito à diversidade e ao pluralismo.

Todavia, dúvidas em torno da constitucionalidade do Acordo de 2008 começaram a surgir no Brasil, principalmente diante de sua entrada em vigor internacional, em 10 de dezembro de 2009, e da publicação, em 12 de fevereiro de 2010, do Decreto $\mathrm{n}^{\circ} 7.107$, de 11 de fevereiro de 2010, que promulgou o Acordo no Brasil. A Procuradoria-Geral da República propôs uma ação direta de inconstitucionalidade em 2 de agosto de 2010, ADI 4439, com o objetivo de que o STF:

(i) realize interpretação conforme a Constituição do art. 33 , caput e $\S \S 1^{\circ}$ e $2^{\circ}$, da Lei $\mathrm{n}^{\circ}$ 9.394/96, para assentar que o ensino religioso em escolas públicas só pode ser de natureza não-confessional, com proibição de admissão de professores na qualidade de representantes das confissões religiosas; (ii) profira decisão de interpretação conforme a Constituição do art. 11, $\S 1^{\circ}$, do "Acordo entre a República Federativa do Brasil e a Santa Sé relativo ao Estatuto Jurídico da Igreja Católica no Brasil", aprovado pelo Congresso Nacional através do Decreto Legislativo $\mathrm{n}^{\mathrm{o}}$ 698/2009 e promulgado pelo Presidente da República através do Decreto $\mathrm{n}^{\circ}$ $7.107 / 2010$, para assentar que o ensino religioso em escolas públicas só pode ser de natureza não-confessional; ou (iii) caso se tenha por incabível o pedido formulado no item imediatamente acima, seja declarada a inconstitucionalidade do trecho 
“católico e de outras confissões religiosas”, constante no art. 11, § 1", do Acordo Brasil-Santa Sé acima referido. (BRASIL, 2010b, p. 01-02).

Os fundamentos expressos na inicial da ADI 4439 pautaram-se numa concepção de ensino religioso que não pode ser proselitista e nem interconfessional, mas sim nãoconfessional, uma vez que nesse modelo "o conteúdo programático da disciplina consiste na exposição das doutrinas, das práticas, da história e de dimensões sociais das diferentes religiões [...] sem qualquer tomada de partido por parte dos educadores." (BRASIL, 2010b, p. 03). Segundo a Procuradoria-Geral da República, este seria o único caminho para que o ensino religioso se tornasse efetivamente laico.

De acordo com a inicial da ADI 4439, o oferecimento de um ensino religioso laico e não-confessional não tem sido uma realidade no Brasil, pois tem ocorrido uma enorme confusão na aplicação do texto legal.

Sem embargo, o art. 33, caput e $\S \S 1^{\circ}$ e $2^{\circ}$, da Lei 9.394/96 vem sendo interpretado e aplicado pelas autoridades públicas competentes como se fosse compatível tanto com o ensino religioso confessional quanto com o interconfessional. Na prática, as escolas públicas brasileiras, com raras exceções, são hoje um espaço de doutrinamento religioso, onde, por vezes, os professores são representantes das igrejas, tudo financiado com recursos públicos. (BRASIL, 2010b, p. 06).

Quanto ao Acordo assinado entre o Brasil e a Santa Sé, a Procuradoria-Geral da República afirma que o art. 11 de seu texto deve ser interpretado de forma a se preservar um ensino religioso não-confessional nas escolas públicas. Tal ensino possibilitaria uma convivência mais democrática entre os alunos e um espaço de maior debate das diferentes manifestações religiosas existentes. Mas, se esta interpretação não for possível, o órgão ministerial entende que o STF poderá "proferir decisão de declaração parcial de inconstitucionalidade com redução de texto, para suprimir da redação do art. $11, \S 1^{\circ}$, do Acordo, a expressão 'católico e de outras confissões religiosas .'. (BRASIL, 2010b, p. 08).

No que diz respeito à laicidade, a Procuradoria-Geral da República entende que tal princípio significa um meio de proteção das religiões de qualquer interferência estatal e, também, da ação das religiões no Estado. Assim, a laicidade proporciona uma ausência de confusão entre os poderes estatal e religioso, pois ambos estão devidamente separados para o exercício de suas funções. Da mesma forma, também a laicidade não pode ser confundida com laicismo. "O laicismo, diferentemente da laicidade, não envolve neutralidade, mas hostilidade diante da religião, e tende a resvalar para posições autoritárias, de restrição a liberdades religiosas individuais." (BRASIL, 2010b, p. 11). 
Pode-se destacar ainda que a Procuradoria-Geral da República, em suas razões na ADI 4439, vinculou a neutralidade do Estado ao princípio da laicidade, o que não deixa de ser uma situação muito comum hoje, já que a compreensão clássica e liberal de laicidade trabalha com o binômio separação e neutralidade estatal. "A laicidade impõe que o Estado se mantenha neutro em relação às diferentes concepções religiosas presentes na sociedade, sendo-lhe vedado tomar partido em questões de fé, bem como buscar o favorecimento ou o embaraço de qualquer crença, ou grupo de crenças.” (BRASIL, 2010b, p. 11).

Por fim, por mais que a ADI 4439 tenha alguns equívocos quanto à compreensão do princípio da laicidade, ela é um importante instrumento para a discussão do ensino religioso nas escolas públicas brasileiras. Tanto é assim que, em 20 de maio de 2015, o Ministro Luís Roberto Barroso, relator da ação, convocou a realização de uma audiência pública para se discutir o modelo de ensino religioso nas escolas públicas, a qual foi realizada em 15 de junho de 2015 e contou com a participação de vários órgãos e entidades da sociedade civil. Desde 18 de junho de 2015, os autos da ADI 4439 estão conclusos ao Ministro Relator e ainda não há data de julgamento para o caso.

\section{ENSINO RELIGIOSO, LAICIDADE E A ÉTICA DA HOSPITALIDADE}

O princípio da laicidade é uma realidade no ordenamento jurídico brasileiro desde o Decreto 119-A/1890, que proibiu o estabelecimento de alguma religião por parte do Estado ou sua vedação, garantiu a igualdade e a liberdade religiosa e extinguiu o regime do padroado no país. Assim, desde o final do século XIX, o princípio da laicidade tem sido definido como sinônimo de neutralidade estatal e de separação entre Estado e religião.

\footnotetext{
A laicidade não significa a adoção pelo Estado de uma perspectiva ateísta ou refratária à religiosidade. Na verdade, o ateísmo, na sua negativa da existência de Deus, é também uma posição religiosa, que não pode ser privilegiada pelo Estado em detrimento de qualquer outra cosmovisão. Pelo contrário, a laicidade impõe que o Estado se mantenha neutro em relação às diferentes concepções religiosas presentes na sociedade, sendo-lhe vedado tomar partido em questões de fé, bem como buscar o favorecimento ou o embaraço de qualquer crença." (SARMENTO, 2009, p. 214).
}

O significado do princípio da laicidade confunde-se com duas premissas básicas do modelo de Estado liberal, a separação e a neutralidade, as quais são imprescindíveis para se 
garantir a igualdade e a liberdade religiosa. "Em uma sociedade igualitária e diversificada, o Estado e as igrejas devem estar separados, e o poder político deve ser neutro em relação às religiões.” (MACLURE; TAYLOR, 2011, p. 21, tradução nossa) ${ }^{1}$.

Contudo, num Estado Democrático de Direito, não é possível afirmar que a compreensão do princípio da laicidade ocorra unicamente a partir da separação e da neutralidade estatal, haja vista não ser possível um distanciamento total entre Estado e religião. Não se pode pensar a religião apenas como algo relegado à esfera privada. Da mesma forma, não há ser humano que consiga ser neutro e imparcial, já que todo conhecimento e toda ação humana ocorrem dentro de uma realidade e de um conjunto de valores e sentidos. Logo, se o ser humano não é neutro, o Estado, consequentemente, também não o será.

\begin{abstract}
Qualquer análise conceitual, por mais que tente ser meramente descritiva, já consiste em um olhar sobre "algo" que só é "algo" na medida de sua significação e de sua referência. Essa significação jamais é neutra, e isso não apenas por já estar, desde sempre, situada em um jogo de linguagem que pretende delimitar os seus sentidos, mas por implicar necessariamente escolhas e ek-stases valorativas, preferências políticas, religiosas, ideológicas, associações. (CRUZ; DUARTE, 2013, p. 73).
\end{abstract}

O princípio da laicidade não pode ser visto apenas dentro de bases fixas e imutáveis. O compreender é permanente e suscetível de mudanças, pois não há conceito que seja fechado. Os conceitos são abertos, estão sujeitos a interpretação e não possuem uma essência única nos moldes reducionistas da metafísica clássica. "A significação das palavras não está estabelecida de modo definitivo (IF 79, 80). O fato de não ser possível conhecer, de modo definitivo, todos os casos de aplicação de uma palavra não significa que ela não tenha sentido." (OLIVEIRA, 2015, p. 130). Uma palavra tem o seu significado estabelecido no uso, no contexto em que possa ser aplicada, não havendo uma interpretação unívoca.

A laicidade não pode significar a adoção de um regime refratário e de exclusão da religião, nos moldes laicistas, pois não há possibilidade de se estabelecer uma separação radical entre Estado e religião. A laicidade está vinculada à preservação da liberdade religiosa, da igualdade e da hospitalidade incondicional, num processo de abertura e de acolhimento ao outro sem limites.

A lei da hospitalidade, a lei formal que governa o conceito geral de hospitalidade, aparece como uma lei paradoxal, perversível ou pervertedora. Ela parece ditar que a hospitalidade absoluta rompe com a lei da hospitalidade como direito ou dever, com

\footnotetext{
${ }^{1}$ En una sociedad igualitaria y diversificada, el Estado y las iglesias deben estar separados, y el poder político debe ser neutro respecto a las religiones.
} 
o "pacto" de hospitalidade. Em outros termos, a hospitalidade absoluta exige que eu abra minha casa e não apenas ofereça ao estrangeiro (provido de um nome de família, de um estatuto social de estrangeiro, etc.), mas ao outro absoluto, desconhecido, anônimo, que eu lhe ceda lugar, que eu o deixe vir, que o deixe chegar, e ter um lugar no lugar que ofereço a ele, sem exigir dele nem reciprocidade (a entrada num pacto), nem mesmo seu nome. A lei da hospitalidade absoluta manda romper com a hospitalidade de direito, com a lei ou a justiça como direito. (DERRIDA, 2003, p. 23-25).

Com isso, o princípio da laicidade do Estado deve passar a ser visto a partir da ética da hospitalidade de Derrida (2003), de forma a fazer com que haja o reconhecimento do outro, de suas diferenças e de sua singularidade, rompendo as barreiras da hostilidade. Uma hospitalidade incondicional promove uma abertura ao outro sem restrições, de forma ilimitada. "A hospitalidade absoluta ou incondicional que eu gostaria de oferecer a ele supõe uma ruptura com a hospitalidade no sentido corrente, com a hospitalidade condicional, com o direito ou o pacto de hospitalidade." (DERRIDA, 2003, p. 23). A lei incondicional da hospitalidade representa uma superação das leis condicionais que sempre estabelecem restrições. É o reconstruir o novo a partir da desconstrução.

\footnotetext{
A hospitalidade passa inevitavelmente pelo endereçamento à singularidade do outro numa cena de dualidade assimétrica, e porque um tal endereçamento compreende já sempre os outros, como magnificamente «Envois» o põe em cena, ela revela-se imediatamente hos-ti-pitalidade - neologismo forjado por Derrida para dizer a hospitalidade incondicional interrompida e contaminada, pervertida, pela hostilidade. (BERNARDO, 2002, p. 422).
}

O princípio da laicidade, numa perspectiva da ética da hospitalidade incondicional, deve ser aberto, acolhedor e que possibilite a realização do pluralismo num Estado Democrático de Direito. Pensar a laicidade nas bases do liberalismo clássico é fazer com que a hostilidade se torne uma realidade presente e que o outro seja desconsiderado e excluído.

\footnotetext{
A hospitalidade justa rompe com o a hospitalidade de direito; não que ela a condene ou se lhe oponha, mas pode, ao contrário, colocá-la e mantê-la num movimento incessante de progresso; mas também lhe é tão estranhamente heterogênea quanto a justiça é heterogênea no direito do qual, no entanto, está tão próxima (na verdade, indissociável). (DERRIDA, 2003, p. 25).
}

Dessa forma, a hospitalidade incondicional promove uma desconstrução do conceito liberal clássico de laicidade, pois este princípio não significa retirar e excluir a religião da esfera pública. A laicidade deve proporcionar o acolhimento, o contato com o outro e a realização de um cuidado incondicional do próximo e de suas diferenças. 
O ensino religioso nas escolas públicas brasileiras deve ser analisado a partir da hospitalidade incondicional de Derrida (2003), numa perspectiva de inclusão, de aceitação do outro e do pluralismo. Com isso, a hospitalidade incondicional fará com que a escola pública se torne um espaço de acolhimento e de aprendizado com o outro e suas diferenças. Tem-se uma abertura para a convivência pacífica e para a troca de experiências com o outro e com as mais distintas concepções religiosas e não religiosas.

A escola pública deve cumprir o seu papel de ser o lugar do aprendizado, do encontro entre diferentes e do compartilhar experiências, valores históricos e distintas concepções de vida. É acolher o outro sem limites, conhecer o desconhecido, já que a convivência entre diferentes faz parte dos grandes desafios da vida. E nada melhor que esta convivência se dê de forma pacífica e de respeito ao outro. Para isso, o ensino religioso pode cumprir um grande papel, pois tornar-se-á uma disciplina que proporcionará uma reflexão sobre as mais diferentes manifestações religiosas existentes na sociedade, uma disciplina que apresente as religiões e as concepções não religiosas e que possa ser útil para a formação cultural dos alunos.

O ensino religioso não pode se constituir numa matéria que tenha por finalidade converter as pessoas a uma determinada concepção religiosa ou não religiosa. Não é possível que tal disciplina seja confessional ou interconfessional, mas sim que seja uma aula de cidadania, de aprendizado e de convivência entre o eu e o outro, numa reflexão democrática sobre as religiões e as concepções não religiosas, as mais diferentes sociedades e modos de vida. Que se possa com isso promover um caminhar além da tolerância, um caminhar que seja de afirmação da hospitalidade incondicional, do aprender com a diversidade e com o outro.

\section{CONCLUSÃO}

A existência do ensino religioso nas escolas públicas brasileiras é uma decorrência direta do processo de formação do Brasil. O cristianismo é parte integrante da história brasileira e deixou marcas na sociedade e no Estado. Assim, a Igreja Católica desempenhou um papel fundamental na edificação do Estado, na identidade e unidade nacionais. Tudo isso fez com que a Constituição do Império de 1824 adotasse o catolicismo como religião oficial e instituísse o regime do padroado no Brasil, possibilitando a existência do ensino religioso nas escolas públicas por meio da Lei de 15 de outubro de 1827. 
Entretanto, a Proclamação da República alterou profundamente o modelo de relações entre Estado e Igreja. O princípio da laicidade foi afirmado, havendo o estabelecimento de uma radical separação entre as esferas estatal e religiosa, o que culminou, por exemplo, com o fim do ensino religioso nas escolas públicas. Mesmo assim, a influência da Igreja Católica no Brasil não acabou por completo. Ela pressionou e agiu em prol da volta do ensino religioso nas escolas públicas, o que aconteceu em Minas Gerais com a Lei 1.092/1929 e, em todo o país, por meio de um decreto do Presidente Getúlio Vargas em 1931. Desde a Era Vargas, o ensino religioso vem fazendo parte da educação brasileira, mantendo-se presente até mesmo na Constituição Cidadã de 1988.

Por mais que a realidade brasileira seja marcada pela existência do ensino religioso nas escolas públicas, a situação ganhou contornos diferentes com a alteração da Lei de Diretrizes e Bases da Educação Nacional, em 1997, e, com a assinatura do Acordo entre o Governo da República Federativa do Brasil e a Santa Sé relativo ao Estatuto Jurídico da Igreja Católica no Brasil em 2008. Contudo, não há que se falar em inconstitucionalidade da lei e do tratado ou ainda em violação ao princípio da laicidade, pois nenhum dos dois textos estabelecem privilégios para a Igreja quanto ao ensino religioso, já que este não será e nem pode ser de viés católico.

A laicidade, num Estado Democrático de Direito, deve ser vista a partir de novas bases, estando aberta ao outro e ao pluralismo religioso. O princípio da laicidade não significa excluir a religião, mas sim hospitalidade incondicional, acolhimento do outro e realização da diversidade, o que faz com que seja possível compatibilizar o ensino religioso com o mencionado princípio.

Dessa forma, deve-se reconstruir a laicidade a partir do outro, sob uma perspectiva que leve em consideração a inclusão, a abertura e o reconhecimento ao outro sem restrições e hostilidades. O ensino religioso deve cumprir uma importante função, qual seja, a de possibilitar o acolhimento e o aprendizado, o que fará com que a escola pública seja o espaço da diversidade, do encontro entre diferentes e que a educação possa transformar as pessoas para o alcance da paz. Que essa seja a perspectiva a ser levada em consideração no julgamento da ADI 4439 pelo STF e que o ensino religioso seja uma disciplina que proporcione o conhecimento das mais diferentes concepções religiosas e não religiosas existentes e assim venha promover a hospitalidade incondicional e o respeito ao outro. 


\section{REFERÊNCIAS}

BERNARDO, Fernanda. A ética da hospitalidade, segundo J. Derrida, ou o porvir do cosmopolitismo por vir a propósito das cidades-refúgio, re-inventar a cidadania (II). In: Revista Filosófica de Coimbra, Coimbra, n.22, 2002, p.421-446.

BRASIL. Constituição (1946). Constituição dos Estados Unidos do Brasil. Disponível em: <http://www.planalto.gov.br/ccivil_03/Constituicao/Constituiçao46.htm>. Acesso em: 10 mar. 2016.

BRASIL. Constituição (1988). Constituição da República Federativa do Brasil. Disponível em: <http://www.planalto.gov.br/ccivil_03/constituicao/constituicao.htm>. Acesso em: 10 mar. 2016.

BRASIL. Decreto $\mathrm{n}^{0}$ 7.107, de 11 de fevereiro de 2010. Promulga o Acordo entre o Governo da República Federativa do Brasil e a Santa Sé relativo ao Estatuto Jurídico da Igreja Católica no Brasil, firmado na Cidade do Vaticano, em 13 de novembro de 2008. Diário Oficial da União, Brasília, 12 fev. 2010. (2010a) Disponível em: <http://www.planalto.gov.br/ccivil_03/_Ato2007-2010/2010/Decreto/D7107.htm>. Acesso em: 17 mar. 2016.

BRASIL. Lei de 15 de outubro de 1827. Manda crear escolas de primeiras letras em todas as cidades, vilas e lugares mais populosos do Império. CLBR, Rio de Janeiro, 15 out. 1827. Disponível em: <http://www.planalto.gov.br/ccivil_03/Leis/LIM/LIM-15-10-1827.htm>. Acesso em: 10 mar. 2016.

BRASIL. Lei n ${ }^{0} 4.024$ de 20 de dezembro de 1961. Fixa as Diretrizes e Bases da Educação Nacional. Diário Oficial da União, Brasília, 27 dez. 1961. Disponível em: <http://www.planalto.gov.br/CCIVIL_03/leis/L4024.htm>. Acesso em: 10 mar. 2016.

BRASIL Lei n ${ }^{\circ} 9.394$ de 20 de dezembro de 1996. Estabelece as diretrizes e bases da educação nacional. Diário Oficial da União, Brasília, 23 dez. 1996. Disponível em: <http://www.planalto.gov.br/ccivil_03/leis/L9394.htm>. Acesso em: 10 mar. 2016.

BRASIL Lei n ${ }^{\circ} 9.475$ de 22 de julho de 1997. Dá nova redação ao art. 33 da Lei n ${ }^{\circ}$ 9.394, de 20 de dezembro de 1996, que estabelece as diretrizes e bases da educação nacional. Diário Oficial da União, Brasília, 23 jul. 1997. Disponível em: <http://www.planalto.gov.br/ccivil_03/leis/L9475.htm>. Acesso em: 10 mar. 2016.

BRASIL. Supremo Tribunal Federal. Ação direta de inconstitucionalidade 4439. Relator: Roberto Barroso. Petição inicial. Procuradoria-Geral da República. (2010b) Disponível em: $<$ http://redir.stf.jus.br/estfvisualizadorpub/jsp/consultarprocessoeletronico/ConsultarProcesso Eletronico.jsf?seqobjetoincidente=3926392 > . Acesso em: 10 mar. 2016.

BUENO, Eduardo. A viagem do descobrimento: a verdadeira história da expedição de Cabral. Rio de Janeiro: Objetiva, 1998. 
CABRAL, Luis Gonzaga. Jesuitas no Brasil (Século XVI). São Paulo: Melhoramentos, 1925.

CHIAVENATO, Júlio José. O negro no Brasil: da senzala à abolição. São Paulo: Moderna, 2002.

CRUZ, Álvaro Ricardo de Souza; DUARTE, Bernardo Augusto Ferreira. Além do positivismo jurídico. Belo Horizonte: Arraes Editores, 2013.

DERRIDA, Jacques. Questão do estrangeiro: vinda do estrangeiro. In:

DUFOURMANTELLE, Anne. Anne Dufourmantelle convida Jacques Derrida a falar da hospitalidade. Tradução de Antonio Romane. São Paulo: Escuta, 2003. p.05-65.

FREYRE, Gilberto. Casa-Grande \& Senzala: formação da família brasileira sob o regime da economia patriarcal. In: SANTIAGO, Silviano. Intérpretes do Brasil. 2. ed. Rio de Janeiro: Nova Aguilar, 2002. v.2. p.105-645.

GUIMARÃES NETO, Samuel Pinheiro. Exposição ao Sr. Presidente da República. In: ANDRADA, Bonifácio de. Acordo do Brasil com a Santa Sé sobre a Igreja Católica: texto do parecer do Deputado Bonifácio de Andrada na Câmara dos Deputados e documentos oficiais. Belo Horizonte: Del Rey, 2009. p.36-40.

MACLURE, Jocelyn; TAYLOR, Charles. Laicidad y libertad de conciencia. Madrid: Alianza Editorial, 2011.

MARIANO, Ricardo. Análise sociológica do crescimento Pentecostal no Brasil. 2001. 285f. Tese (Doutorado) - Universidade de São Paulo, Faculdade de Filosofia, Letras e Ciências Humanas, São Paulo.

MICELI, Sérgio. A elite eclesiástica brasileira: 1890-1930. São Paulo: Companhia das Letras, 2009.

OLIVEIRA, Manfredo A. Reviravolta linguístico-pragmática na filosofia contemporânea. São Paulo: Edições Loyola, 2015.

REIS, António do Carmo. Nova história de Portugal. Lisboa: Notícias, 1990.

SARMENTO, Daniel. O crucifixo nos tribunais e a laicidade do Estado. In: MAZZUOLI, Valerio de Oliveira; SORIANO, Aldir Guedes (Coords.). Direito à liberdade religiosa: desafios e perspectivas para o século XXI. Belo Horizonte: Fórum, 2009. p.211-234.

VIANNA, Hélio. História do Brasil: período colonial. 8. ed. São Paulo: Edições Melhoramentos, 1970. 